\title{
Use of functional traits to assess changes in stream fish assemblages across a habitat gradient
}

\author{
Mariela Domiciano Ribeiroํㅜ Fabrício Barreto Teresa ${ }^{2}$ and Lilian Casatti ${ }^{1}$
}

Functional traits are important for understanding the links between species occurrence and environmental conditions. Identifying these links makes it possible to predict changes in species composition within communities under specific environmental conditions. We used functional traits related to habitat use and trophic ecology in order to assess the changes in fish community composition between streams with varying habitat structure. The relationship between the species traits and habitat characteristics was analyzed using an RLQ ordination analysis. Although species were widely distributed in habitats with different structures, physical conditions did favor some species based on their functional characteristics. Eight functional traits were found to be associated with stream habitat structure, allowing us to identify traits that may predict the susceptibility of fish species to physical habitat degradation.

Os atributos funcionais são importantes para entender a ligação entre ocorrência das espécies e condições ambientais, permitindo predizer sobre as mudanças na composição de espécies em comunidades submetidas a condições ambientais específicas. Utilizamos atributos funcionais relacionados com o uso de habitat e ecologia trófica para avaliar as mudanças na composição de espécies de peixes em riachos com diferenças na estrutura física. O relacionamento entre os atributos das espécies e as variáveis ambientais foi avaliado por meio da análise de ordenação RLQ. Embora algumas espécies tenham sido amplamente distribuídas em hábitats com diferentes características, outras foram restritas por essas condições e este relacionamento está associado com as características morfológicas. Oito atributos funcionais foram capazes de detectar as variações na estrutura física do hábitat em riachos, permitindo a identificação de atributos que podem predizer a suscetibilidade das espécies de peixes para a degradação física do hábitat.

Keywords: RLQ analysis, Agroecosystem, Freshwater, Tropical fish, Morphology.

\section{Introduction}

Understanding the relationships between the environment and biological diversity is a central goal of ecological studies (Townsend \& Hildrew, 1994). Because of the rapidity with which ecosystems have suffered from changes due to anthropogenic activities, knowledge of ecological relationships is urgently needed when attempting to predict the biological consequences of such modifications. This is particularly relevant in Neotropical aquatic ecosystems, which are among the most diverse on earth and where physical, chemical, and biological conditions are being altered by various forms of anthropogenic impact (Barletta et al., 2010).

Streams running through agroecosystems can exhibit a gradient of physical habitat conditions, from degraded streams with less complex habitats that are lacking a riparian canopy to more preserved streams with a more complex habitat composed of consolidate substrates, a canopy, and woody debris in the channel (Casatti et al., 2009). Environments that experience these types of alterations are subject to changes in community composition in a non-random way. The decline of some populations or the increase of some species that are favored by environmental changes (e.g., Lorion \& Kennedy, 2009) may be predicted by specific combination of traits (McKinney \& Lockwood, 1999). The identification of the functional traits correlated with habitat gradients contributes to the ability to predict species responses to human impacts; for example, it would be possible to identify the species most susceptible to habitat degradation (Hausner et al., 2003).

${ }^{1}$ UNESP - Universidade Estadual Paulista, Laboratório de Ictiologia, Departamento de Zoologia e Botânica, IBILCE, Rua Cristóvão Colombo, 2265, 15054-000 São José do Rio Preto, SP, Brazil. (MDR) marieladomiciano@gmail.com (corresponding author), (LC) licasatti@gmail.com

${ }^{2}$ UEG - Universidade Estadual de Goiás, Unidade Universitária de Ciências Exatas e Tecnológicas, Rodovia BR 153, 3.105, Fazenda Barreiro do Meio, Caixa Postal 459, 75132-903 Anápolis, GO, Brazil. (FBT) fabricioteresa@yahoo.com.br 
Previous studies have demonstrated that some morphological attributes are strongly correlated with species habitat use and trophic ecology (Gatz, 1979; Mahon, 1984; Watson \& Balon, 1984; Casatti \& Castro, 2006; Oliveira et al., 2010). These studies are the foundation for the investigation of these morphological attributes as functional traits, providing a quick, easy, and informative way to obtain ecological information about fish species (Pool et al., 2010; Villéger et al., 2010; Pease et al., 2012; Schleuter et al., 2012). The use of functional traits based on morphology is especially important in regions where descriptions of functional ecology are hampered by gaps in the autoecological knowledge of fish fauna, which is a particular problem in the Neotropics.

We tested the association of morphological functional traits with physical habitat structure in streams. This study was carried out using a large database (91 streams) in the northwest area of the state of São Paulo in southeast Brazil, a region that was originally covered by Semideciduous Seasonal Forest (Silva et al., 2007). Intensive deforestation in this region began in the second half of the nineteenth century (Monbeig, 1998), with the remaining 4\% of the original vegetation coverage (Nalon et al., 2008) distributed in small fragments (Silva et al., 2007). As a result, there is a clear gradient of physical habitat integrity, which is expected to influence the structure and composition of fish communities (Casatti et al., 2009). We hypothesized that shifts in the community composition in streams with different physical structure would reflect a trait-habitat relationship. Accordingly, we predicted that functional traits of fishes are not randomly distributed but rather are correlated with physical habitat.

\section{Material and Methods}

Study area. We performed this study exclusively in nonurban areas of the hydrographical basins of the rio São José dos Dourados and rio Turvo-Grande (tributaries of the rio Paraná), located in the northwest region of São Paulo State, Brazil (Fig. 1). For this study, we selected only streams that are embedded in agricultural lands used primarily for livestock grazing or sugarcane cultivation.

The soil of this region is characterized by sandy and unconsolidated clay sediments that have high erosion potential (IPT, 1999). The climate is hot and tropical, with maximum temperatures near $32^{\circ} \mathrm{C}$, minimum temperatures near $13^{\circ} \mathrm{C}$, and annual rainfall between 1,300 and 1,800 $\mathrm{mm}$ (Silva et al., 2007). The region has a well-defined dry period with lower rainfall between June and August, and a wet period with higher rainfall between December and January (Instituto de Pesquisas Tecnológicas do Estado de São Paulo (IPT), 1999).

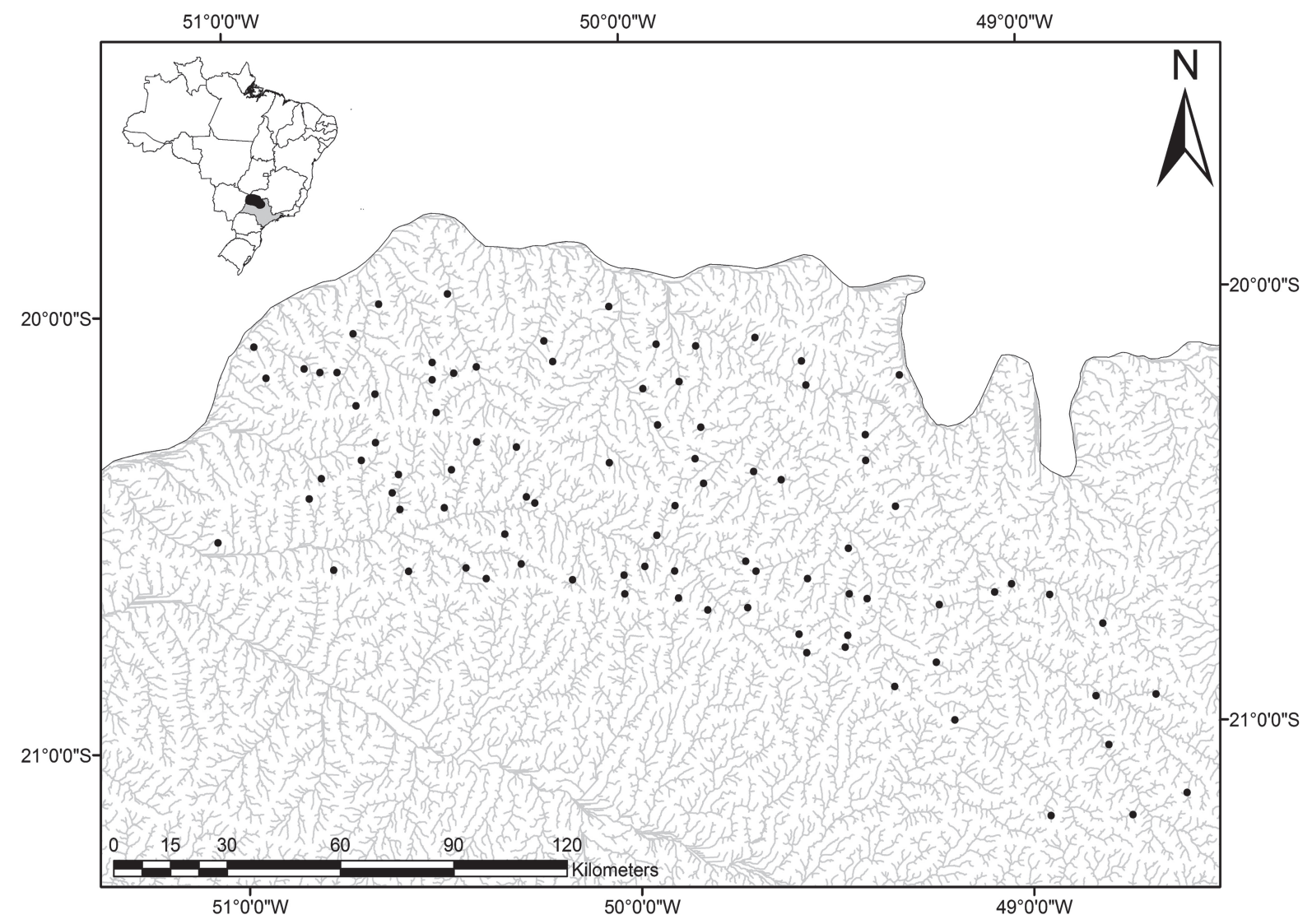

Fig. 1. Location of the study area in the northwestern region of São Paulo State, Brazil (black area on the country map), showing the 91 streams sampled. 
Data collection. The sites were selected for sampling according to a randomized approach. One site was chosen for each $100 \mathrm{~km}$ of a stream of specific order (from first to third order, as determined on a 1:50,000 map scale, sensu Strahler, 1957). Ninety five stream reaches were sampled once during the dry season from 2003 to 2005 to minimize the effects of any seasonal differences. From the data set obtained, we used 91 reaches because they had the minimum number of three species, necessary to carry out the analysis. We collected fish by two electrofishing passes along $75 \mathrm{~m}$ stream reaches, using an $\mathrm{AC}$ generator $(220 \mathrm{~V}$, 50-60 Hz, 3.4-4.1 A, $1000 \mathrm{~W})$. Fish were euthanized with an overdose of clove oil and fixed in a $10 \%$ formaldehyde solution. In the laboratory, fish were transferred to a $70 \%$ ethanol solution 48 hours after sampling. Species were identified, and all collected specimens were deposited in the fish collection at the Departamento de Zoologia e Botânica, Universidade Estadual Paulista, São José do Rio Preto, São Paulo, Brazil (DZSJRP).

In each stream, we quantified the following 10 habitat variables: (1) \% of the stream bed composed of clay, (2) $\%$ of the stream bed composed of sand, (3) \% of the stream bed composed of gravel, (4) \% of the stream bed composed of rock, (5) \% of the stream bed composed of boulders, (6) \% of the stream bed composed of bedrock (in total, accounting for $100 \%$ of stream bottom coverage), (7) $\%$ of the instream habitat occupied by woody debris, (8) \% of both banks covered by grasses (grasses consisted primarily of the invasive weed Brachiaria spp. that proliferated on banks near pastures), (9) \% of both banks covered by trees, (10) \% of both banks covered by shrubs. For variables 8 to 10 , a riparian strip of $10 \mathrm{~m}$ in width was considered.

We determined values for 10 morphological traits (Table 1) that were measured or calculated by Gatz (1979), Blake (1983), Mahon (1984), and Watson \& Balon (1984). The morphological traits are mainly related to fish specializations for swimming ability, position in the water column, prey size, and foraging site (see calculations and explanations in Table 1). We recognize that reproductive ecology and life-history traits play a relevant role in the manner in which species respond to environmental gradients (Goldstein \& Meador, 2005; Winemiller et al., 2015); however, the information available on reproduction and life-history was limited to a relatively few species of our dataset, thereby precluding the use of these traits in our study. To quantify the morphological traits listed in Table 1 , we measured 15 individuals from each of the 60 species collected (Table 2), for a total of 900 individuals. When the number of specimens per species was less than 15 , the sample was supplemented by specimens from the DZSJRP collection, using lots from the same watershed whenever possible. Body and fin measurements were taken with a digital caliper. The body area, pectoral-fin area, and mouth angle were measured with the aid of a stereomicroscope (ZeissV12) and the imaging software AxioVision Zeiss. In large-sized specimens, we determined the area of the body and pectoral fins by contouring the structures on graph paper (Beaumord \& Petrere Jr., 1994). For specimens of Poecilia reticulata and Phalloceros harpagos, which exhibit sexual dimorphism, only females were measured.

Analysis. We conducted an RLQ ordination analysis to analyze the relationship between species functional traits and habitat structure (Dolédec et al., 1996). This procedure links species traits to habitat variables and has been shown to be a powerful tool for identifying the set of traits that are associated with environmental changes (Hausner et al., 2003). This multivariate technique is based on the ordination of three matrices (Dolédec et al., 1996): the $\mathrm{R}$ matrix has streams as rows, habitat variables as columns, and values for each environmental variables as entries; the L matrix has sites as rows, species as columns, and species abundances as entries; and the Q matrix has species as rows, functional morphological traits as columns, and morphological trait values as entries. We square root transformed the L matrix, which was the link between the $\mathrm{R}$ and $\mathrm{Q}$ matrices, to minimize the differences between abundant and rare species. The $\mathrm{R}$ and $\mathrm{Q}$ matrices were standardized (mean 0, standard deviation 1) to permit comparisons of variables measured at different scales (Melo \& Hepp, 2008).

Prior to the RLQ ordination, a separate ordination analysis was performed for each matrix (Vallet et al., 2010). We conducted a Correspondence Analysis (CA) with the L matrix. Using the site scores obtained from the CA, we conducted a Principal Component Analysis (PCA) with the $\mathrm{R}$ matrix. Using the species scores obtained from the $\mathrm{CA}$, we performed a Principal Coordinates Analysis (PCoA) with the Q matrix using the Euclidean Distance. After ordering the three matrices separately, we constructed a joint ordination of the three matrices (RLQ) based on the scores from the ordination of matrix L. An RLQ analysis based on the CA abundance matrix allows the obtainment of new site and species scores with the maximum covariance (Dolédec et al., 1996). RLQ maximizes the covariation between habitat variables and species traits by combining the results of three separate analyses using the CA coordinates ( $\mathrm{L}$ matrix) as a link between the R and Q matrices (Hausner et al., 2003).

We tested the statistical significance of associations between functional traits and habitat variables in the RLQ analysis using a permutation test in which the species and sample units were permuted in R and Q simulated matrices (null model 5 according to Dray \& Legendre, 2008). The null model hypothesis is that the distribution of species among sites is related to neither the structural condition of the streams nor the functional traits of those species. As this test has a high chance of type I error, we also performed tests based on null models 2 (permutations of sites in the R matrix) and 4 (permutations of species in the Q matrix), as recommended in Dray \& Legendre 
(2008). For this analysis, we used the R software ( $R$ Development Core Team, 2011) with the ade4 package (Dray \& Dufour, 2007). To complement these analyses, we calculated the correlations between coordinates along the most significant axis of the RLQ and the coordinates for the variables using the Pearson correlation analysis in the Statistica 7.0 software (StatSoft Inc., 2004). We were thus able to determine if the different habitat structures represented by the first axis of the RLQ were significant. To determine which functional traits were responsible for the species distributions according to habitat structure, we conducted a Pearson correlation analysis between the scores of the species along the most significant axis of the RLQ analysis and the original values for the functional traits. Since several tests were conducted, we used the Šidák correction to adjust the alpha level (Šidák, 1967).

Table 1. Functional traits related to habitat use and trophic ecology. Measurements were taken according to Winemiller (1991) and Casatti \& Castro (2006). SL = standard length.

\begin{tabular}{|c|c|c|}
\hline Traits & Calculation & Interpretation \\
\hline \multicolumn{3}{|c|}{ Habitat use } \\
\hline Compression index & $\begin{array}{l}\text { Maximum height of the body divided by its } \\
\text { maximum width }\end{array}$ & $\begin{array}{l}\text { High values may indicate a laterally compressed fish, inhabiting } \\
\text { lentic habitats (Watson \& Balon, 1984) }\end{array}$ \\
\hline Relative depth & Maximum height of the body divided by SL & $\begin{array}{l}\text { Low values indicate fish inhabiting fast waters. Body depth is } \\
\text { directly related to the ability to perform vertical spins (Gatz, 1979) }\end{array}$ \\
\hline Index of ventral flattening & $\begin{array}{l}\text { Mid-line height divided by the maximum body } \\
\text { height }\end{array}$ & $\begin{array}{c}\text { Low values indicate fishes inhabiting environments with high } \\
\text { hydrodynamism that are able to maintain their spatial position even } \\
\text { when stationary (Hora, 1930) }\end{array}$ \\
\hline Relative area of pectoral fin & Pectoral fin area divided by body area & $\begin{array}{l}\text { High values indicate slow swimmers that use pectoral fins to } \\
\text { perform maneuvers and breakings, or fish inhabiting fast waters, } \\
\text { which use their pectoral fins as airfoils to deflect the water current } \\
\text { upwards and thereby maintain themselves firmly attached to the } \\
\text { substrate (Mahon, 1984; Watson \& Balon, 1984) }\end{array}$ \\
\hline Pectoral fin aspect ratio & $\begin{array}{l}\text { Maximum length of the pectoral fin divided by } \\
\text { its maximum width }\end{array}$ & $\begin{array}{c}\text { High values indicate long fins, typical of fish that swim for long } \\
\text { distances (Watson \& Balon 1984) or pelagic fish that swim } \\
\text { constantly (Casatti \& Castro, 2006) }\end{array}$ \\
\hline Relative eye position & $\begin{array}{l}\text { Distance from the middle of the eye to the base } \\
\text { of the head divided by the head height }\end{array}$ & $\begin{array}{l}\text { Position of eyes is assumed to be related to vertical habitat } \\
\text { preference (Gatz, 1979). High values indicate dorsally located eyes, } \\
\text { typical of benthic fish (Mahon, 1984; Watson \& Balon, 1984) }\end{array}$ \\
\hline Fineness coefficient & $\begin{array}{l}\text { SL divided by the square root of the maximum } \\
\text { height of the body, multiplied by the maximum } \\
\text { body width }\end{array}$ & $\begin{array}{l}\text { Assesses the influence of body shape on the ability to swim. Values } \\
\text { from } 2 \text { to } 6 \text { indicate low drag; the optimum ratio for swimming } \\
\text { efficiency is } 4.5 \text { (Blake, 1983) }\end{array}$ \\
\hline \multicolumn{3}{|c|}{ Trophic ecology } \\
\hline Relative head length & $\begin{array}{l}\text { Distance from tip of snout to the margin of the } \\
\text { operculum divided by SL }\end{array}$ & $\begin{array}{l}\text { High values may indicate fish able to feed on relatively larger prey } \\
\text { (Watson \& Balon, 1984) }\end{array}$ \\
\hline Relative mouth width & Mouth width divided by SL & $\begin{array}{l}\text { High values indicate fish able to feed on relatively large prey (Gatz, } \\
\qquad 1979)\end{array}$ \\
\hline Mouth orientation & $\begin{array}{l}\text { Angle between the tangential plane to both lips } \\
\text { and the longitudinal axis of the body }\end{array}$ & $\begin{array}{l}\text { Mouth orientation indicates from which part of the habitat the fish } \\
\text { gets its food. For example, fish with ventral mouths feed on prey } \\
\text { at the bottom }(\mathrm{Gatz}, 1979) \text {. Mouth orientation was characterized as } \\
\text { follows: inferior }=\text { between } 10^{\circ} \text { and } 80^{\circ} \text {; terminal }=90^{\circ} \text {; superior }= \\
\text { between } 100^{\circ} \text { and } 170^{\circ} \text {; ventral }=0^{\circ} \text {. Degree values were converted } \\
\text { to radians (unit of plane angle) }\end{array}$ \\
\hline
\end{tabular}

\section{Results}

The species distribution across differently structured habitats (the average position and standard deviation of species in the habitat gradient) is shown in Fig. 2. Most species were widely distributed throughout the study area, with a few species restricted to extremes. The first axis of the RLQ analysis, representing the correlation between species functional traits and habitat structure, accounted for $84.6 \%$ of the total variation. When correlating the RLQ with the individual $\mathrm{R}$ and $\mathrm{Q}$ matrices, the first RLQ axis represented $93.0 \%$ of the variability explained by the PCA (habitat structure) and $88.2 \%$ of the variability explained by the PCoA (functional traits). This result indicates that the gradient represented by the first RLQ axis was similar to the gradient described by the separate analyses. 
Table 2. Species registered in the 91 streams, listed according the taxonomic classification of Buckup et al. (2007), their codes, and voucher numbers. Asterisks denote non-native species to the Paraná basin.

\begin{tabular}{|c|c|c|c|}
\hline Taxa & Species and authors & Codes & Voucher (DZSJRP) \\
\hline \multicolumn{4}{|c|}{ CHARACIFORMES } \\
\hline Acestrorhynchidae & Acestrorhynchus lacustris (Lütken,1875) & Acelac & 5943 \\
\hline \multirow{4}{*}{ Anostomidae } & Leporinus friderici (Bloch, 1794) & Lepfri & 6169 \\
\hline & Leporinus lacustris Campos, 1945 & Leplac & 7674 \\
\hline & Leporinus paranensis Garavello \& Britski, 1987 & Leppar & 5907 \\
\hline & Leporinus striatus Kner, 1858 & Lepstr & 6170 \\
\hline \multirow{16}{*}{ Characidae } & Astyanax fasciatus (Cuvier, 1819) & Astfas & 5876 \\
\hline & Astyanax lacustris (Lütken,1875) & Astlac & 5834 \\
\hline & Astyanax paranae Eigenmann, 1914 & Astpar & 9597 \\
\hline & Astyanax bockmanni Vari \& Castro, 2007 & Astboc & 9564 \\
\hline & Hemigrammus marginatus Ellis, 1911 & Hemmar & 5835 \\
\hline & Hyphessobrycon anisitsi (Eigenmann, 1907) & Hypani & 9872 \\
\hline & Hyphessobrycon eques (Steindachner, 1882) & Hypequ & 7370 \\
\hline & Knodus moenkhausii (Eigenmann \& Kennedy, 1903) & Knomoe & 6089 \\
\hline & Moenkhausia sanctaefilomenae (Steindachner, 1907) & Moesan & 5905 \\
\hline & Oligosarcus pintoi Campos, 1945 & Olipin & 5838 \\
\hline & Piabina argentea Reinhardt, 1867 & Piaarg & 5836 \\
\hline & Planaltina britskii Menezes, Weitzman \& Burns, 2003 & Plabri & 5885 \\
\hline & Serrapinnus heterodon (Eigenmann, 1915) & Serrhet & 9653 \\
\hline & Serrapinnus notomelas (Eigenmann, 1915) & Serrnot & 5837 \\
\hline & Serrasalmus maculatus Kner, 1858 & Sermac & 16088 \\
\hline & Serrasalmus marginatus Valenciennes, 1837 & Sermar & 5940 \\
\hline \multirow{3}{*}{ Crenuchidae } & Characidium gomesi Travassos, 1956 & Chagom & 8076 \\
\hline & Characidium aff. lagosantense Travassos, 1947 & Chalag & 6092 \\
\hline & Characidium zebra Eigenmann, 1909 & Chazeb & 5962 \\
\hline \multirow{3}{*}{ Curimatidae } & Cyphocharax modestus (Fernández-Yépez, 1948) & Cypmod & 5963 \\
\hline & Cyphocharax vanderi (Britski, 1980) & Cypvan & 5839 \\
\hline & Steindachnerina insculpta (Fernández-Yépez, 1948) & Steins & 5944 \\
\hline \multirow{2}{*}{ Erythrinidae } & Erythrinus erythrinus (Bloch \& Schneider, 1801) & Eryery & 9721 \\
\hline & Hoplias malabaricus (Bloch, 1794) & Hopmal & 5833 \\
\hline Lebiasinidae & Pyrrhulina australis Eigenmann \& Kennedy, 1903 & Pyraus & 6087 \\
\hline \multirow{2}{*}{ Parodontidae } & Apareiodon piracicabae (Eigenmann, 1907) & Apapir & 6167 \\
\hline & Parodon nasus Kner, 1858 & Parnas & 5852 \\
\hline Prochilodontidae & Prochilodus lineatus (Valenciennes, 1836) & Prolin & 9696 \\
\hline \multicolumn{4}{|c|}{ SILURIFORMES } \\
\hline \multirow{5}{*}{ Callichthyidae } & Aspidoras fuscoguttatus Nijssen \& Isbrücker, 1976 & Aspfus & 5855 \\
\hline & Callichthys callichthys (Linnaeus, 1758) & Calcal & 5843 \\
\hline & Corydoras aeneus (Gill, 1858) & Coraen & 5841 \\
\hline & Hoplosternum littorale (Hancock, 1828) & Hoplit & 7374 \\
\hline & Lepthoplosternum pectorale (Boulenger, 1895) & Leppec & 9829 \\
\hline \multirow{6}{*}{ Heptapteridae } & Cetopsorhamdia iheringi Schubart \& Gomes, 1959 & Cetihe & 5995 \\
\hline & Imparfinis mirini Haseman, 1911 & Impmir & 5840 \\
\hline & Imparfinis schubarti (Gomes, 1956) & Impsch & 6171 \\
\hline & Phenacorhamdia tenebrosa (Schubart, 1964) & Pheten & 9592 \\
\hline & Pimelodella avanhandavae Eigenmann, 1917 & Pimava & 5895 \\
\hline & Rhamdia quelen (Quoy \& Gaimard, 1824) & Rhaque & 5864 \\
\hline \multirow{3}{*}{ Loricariidae } & Hisonotus francirochai (Ihering, 1928) & Hisfra & 9868 \\
\hline & Hypostomus ancistroides (Ihering, 1911) & Hypanc & 5844 \\
\hline & Hypostomus sp. & Hypsp & 6106 \\
\hline
\end{tabular}




\begin{tabular}{|c|c|c|c|}
\hline Taxa & Species and authors & Codes & Voucher (DZSJRP) \\
\hline \multicolumn{4}{|c|}{ GYMNOTIFORMES } \\
\hline \multirow{2}{*}{ Gymnotidae } & Gymnotus sylvius Albert \& Fernandes-Matioli, 1999 & Gymsyl & 5845 \\
\hline & Gymnotus inaequilabiatus (Valenciennes, 1839) & Gymina & 6018 \\
\hline Sternopygidae & Eigenmannia virescens (Valenciennes, 1842) & Eigvir & 5969 \\
\hline \multicolumn{4}{|c|}{ PERCIFORMES } \\
\hline \multirow{7}{*}{ Cichlidae } & Cichlasoma paranaense Kullander, 1983 & Cicpar & 5858 \\
\hline & Crenicichla britskii Kullander, 1982 & Crebri & 5846 \\
\hline & Geophagus brasiliensis (Quoy \& Gaimard, 1824) & Geobra & 5859 \\
\hline & Laetacara aff. araguaiae (Ottoni \& Costa, 2009 ) & Laeara & 6152 \\
\hline & Oreochromis niloticus (Linnaeus, 1758) & Orenil & 6115 \\
\hline & Satanoperca pappaterra $($ Heckel, 1840) & Satpap & 6061 \\
\hline & *Tilapia rendalli (Boulenger, 1897) & Tilren & 6043 \\
\hline \multicolumn{4}{|c|}{ CYPRINODONTIFORMES } \\
\hline \multirow{2}{*}{ Poeciliidae } & Phalloceros harpagos Lucinda, 2008 & Phahar & 9818 \\
\hline & *Poecilia reticulata Peters, 1859 & Poeret & 5857 \\
\hline Rivulidae & Rivulus pictus Costa, 1989 & Rivpic & 6124 \\
\hline
\end{tabular}

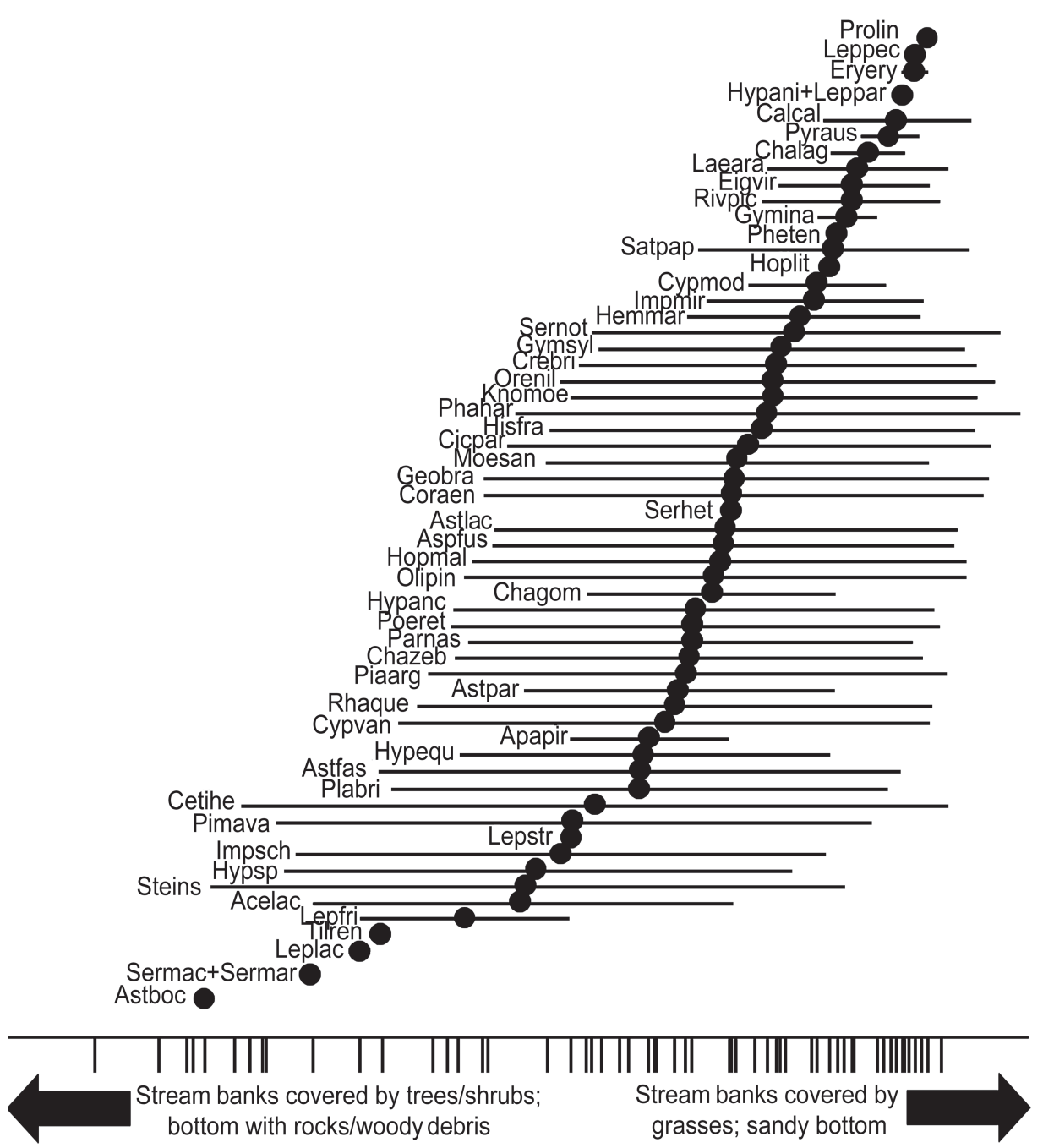

Fig. 2. Average position of species occurrence along the gradient of habitat structure (dark circles). The horizontal bars indicate the standard deviation of the mean position of each species, and the vertical bars at the bottom of the graph represent the position of each stream along the habitat gradient (axis 1 of RLQ). Species codes are presented in Table 2. 
The first RLQ axis was positively correlated with the proportion of sand on the bottom and grass on the banks and negatively related to the other variables, with the exception of the proportion of bedrock (Fig. 3). Therefore, the first RLQ axis represents, at one extreme, the streams with less complex habitats, e.g., with sandy bottoms and a banks covered by grasses; and at the other extreme, relatively more complex streams, e.g., with consolidate substrates (pebbles and gravel), shrubs and trees in the riparian buffer, and woody debris in the channel.

Relationship between habitat variables and functional traits was significant (null models 2, 4, and 5, $P<0.05$ ). The compression index, relative area of pectoral fin, index of ventral flattening, mouth orientation, fineness coefficient, pectoral fin aspect ratio, relative eye position, and relative mouth width were significantly correlated with the first RLQ axis $(P<0.01)$ (Fig. 4). Species with compressed bodies, long and narrow pectoral fins, and a terminal mouth, were correlated with streams that have large amounts of grass in the banks and sandy bottom (less complex sites). In contrast, species with large pectoral fins, dorsally located eyes, and larger mouth width were correlated with streams that have trees/shrubs covering the banks and rocks/woody debris in the bottom (more complex sites).

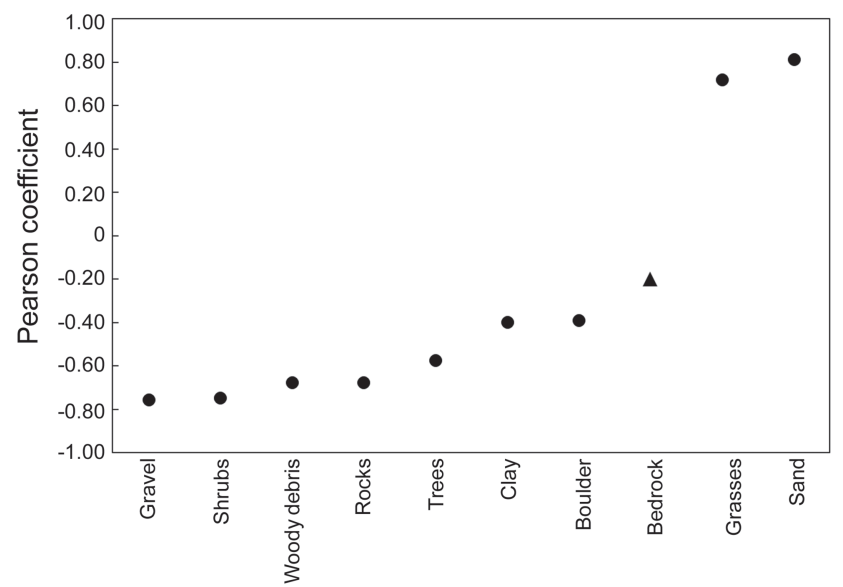

Fig. 3. Pearson correlation between the stream scores of the first RLQ axis and the original values of the environmental variables. All correlations were significant (Pearson correlation, $P<0.05$ ), except for the proportion of bedrock in the substrate (triangle).

\section{Discussion}

We found a strong correlation between functional traits and habitat structure. Our results on trait-habitat linkages are similar to previous studies investigating other organisms and habitats (Ribera et al., 2001; Hausner et al., 2003; Pease et al., 2012). Such findings reinforce the predictive power of the trait-environment approach and suggest that functional traits related to habitat use and trophic ecology can be useful for predicting the vulnerability of species to changes in the physical structure of streams.
Analytical approach used here allowed for the identification of traits that were significantly associated with a gradient of physical habitat complexity. An alternative method would be an evaluation of the spatial distribution of functional groups (Teresa et al., 2015). However, in addition to problems with group formation, the premise of this approach is that species within a group are identical and species from different groups are equally different; this assumption is not necessarily true (Petchey \& Gaston, 2006), particularly when analyzing continuous traits, as it was done here. The trait-environment relationship could also be elucidated using a descriptive approach to explain the species distribution along environmental gradient based on their functional traits rather than an analytical approach. Although a descriptive methodology may be simple to implement, the interpretation could be complex due the multivariate character of the functional traits matrix (10 dimensions in our study), and thus the significance of the relationships could not be evaluated. RLQ is a speciesbased method that considers single species response to an environmental gradient (Kleyer et al., 2012) and has the advantage of explicitly incorporating the three types of fundamental ecological data used in trait-environment relationship studies (i.e., a species functional trait matrix, an environmental matrix and a species co-occurrence matrix). These advantages make the approach taken here suitable for evaluating trait-environment relationships (Vallet et al., 2010; Kleyer et al., 2012; Pease et al., 2012; Keck et al., 2014).

The first RLQ axis represented the variation in habitat structure, contrasting streams that were less structurally complex (i.e., large amount of grasses in the banks and sandy bottom, which is typical for streams running through agricultural land, which lack riparian canopy), with streams that are more structurally complex (i.e., a consolidated substrate, shrubs and trees in the riparian buffer, and woody debris in the channel, which is typical of more preserved streams) (Casatti et al., 2009). As hypothesized, the distribution of species between habitats with differing physical structure was not random; eight of the ten traits were correlated with habitat structure when tested using the null model approach. Species characterized by large pectoral fins, flattened bodies, dorsally positioned eyes, and ventral mouths were associated with more structurally complex streams. These traits are characteristic of fish with benthic, rheophilic habits (Watson \& Balon, 1984; Oliveira et al., 2010; Teresa \& Casatti, 2012), such as Hypostomus sp., Imparfinis schubarti, and Cetopsorhamdia iheringi (see Fig. 2). A correlation between rheophilic species and more preserved sites has also been noted previously (Kamdem Toham \& Teugels, 1999) and likely arises because riffles tend to disappear in degraded streams due to the degradation of the riparian zone and increased sedimentation, which causes the burial of stable substrates and a consequent reduction of flow (Berkman \& Rabeni, 1987). 

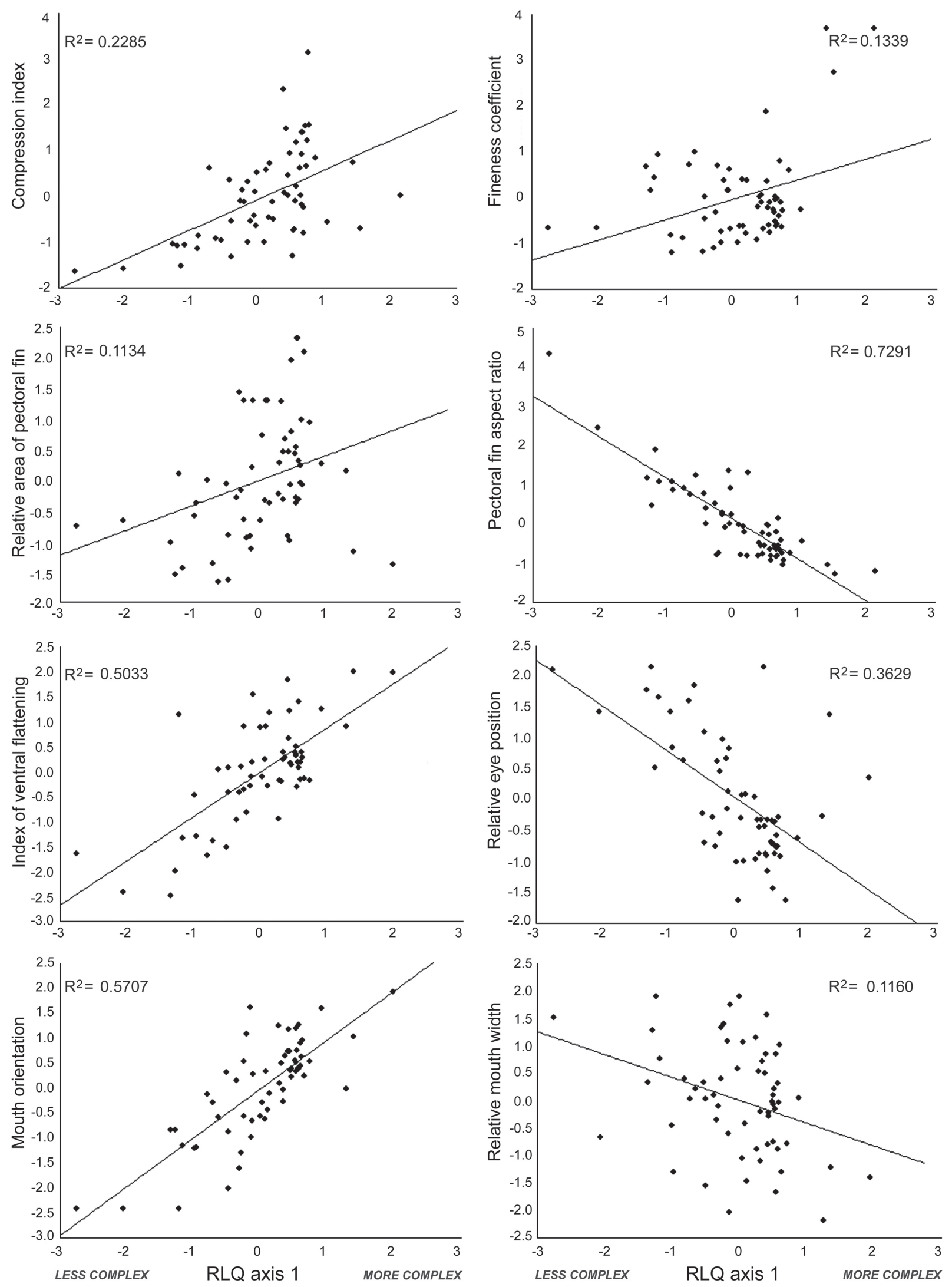

Fig. 4. Functional traits significantly correlated with the first RLQ axis (Pearson correlation, $P<0.005$ ). In each graph, the first RLQ axis represents streams with banks covered by grasses and sandy bottom (less complex) and streams with banks covered by trees/shrubs and bottom with rocks/woody debris (more complex). 
Species associated with less structurally complex streams displayed high and laterally compressed bodies, long and narrow pectoral fins, and terminal mouths. These characteristics were associated with lentic environments and are found in fish with primarily nektonic or nektobenthic habits (Watson \& Balon, 1984). The species that share these characteristics could be divided into three groups according to the microhabitats they occupy: open water species that occupy marginal pools and capture drifting food items (e.g., Serrapinnus notomelas and Hemigrammus marginatus); sedentary species associated with reduced flow in submerged grasses along stream banks (e.g., Hoplosternum littorale, Leptoplosternum pectorale, Gymnotus sylvius, Satanoperca pappaterra, Laetacara aff. araguaiae, Eigenmannia virescens, Erythrinus erythrinus, and Callichthys callichthys); and species that occupy shallow lateral segments and capture drifting food items (e.g., Rivulus pictus and Pyrrhulina australis).

Using the same dataset as this study, Casatti et al. (2009) also demonstrated clear differences in the species composition between streams with different habitat structure. Taken together, these two studies imply that species replacement along a gradient of habitat structure is associated with functional traits, which further suggests that physical anthropogenic degradation of Neotropical streams influences community composition in predictable ways.

\section{Acknowledgements}

The authors thank their colleagues at the Laboratório de Ictiologia for their assistance with field work; IBAMA for a collecting license (001/2003); landowners for permission to access study sites; Francisco Langeani for fish identification; Maria Stela M. Castilho-Noll, Denise de C. Rossa Feres, Fábio C. Ferreira, Paulo S. Pompeu, and other reviewers for their suggestions; and Gabriel L. Brejão for help with Figure 1. This study received financial support from FAPESP (2001/13340-7, 2010/13923-1). FBT was supported by PROBIP/UEG, CAPES and Fundação de Amparo à Pesquisa do Estado de Goiás (Auxpe 2036/2013). LC was supported by CNPq (301755/2013-2).

\section{References}

Barletta, M., A. J. Jaureguizar, C. Baigun, N. F. Fontoura, A. A. Agostinho, V. M. F. Almeida-Val, A. L. Val, R. A. Torres, L. F. Jimenes-Segura, T. Giarrizzo, N. N. Fabré, V. S. Batista, C. Lasso, D. C. Taphorn, M. F. Costa, P. T. Chaves, J. P. Vieira \& M. F. M. Corrêa. 2010. Fish and aquatic habitat conservation in South America: a continental overview with emphasis on Neotropical systems. Journal of Fish Biology, 76: 2118-2176.

Beaumord, A. C. \& M. Petrere Jr. 1994. Comunidades de peces del rio Manso, Chapada dos Guimarães, MT, Brasil. Acta Biologica Venezuelica, 15: 21-35.

Berkman, H. E. \& C. F. Rabeni. 1987. Effect of siltation on stream fish communities. Environmental Biology of Fishes, 18: 285-294.
Blake, R. W. 1983. Functional design and burst-and-coast swimming in fishes. Canadian Journal of Zoology, 61: 24912494.

Buckup, P. A., N. A. Menezes \& M. S. Ghazzi (Eds.). 2007. Catálogo das espécies de peixes de água doce do Brasil. Rio de Janeiro, Museu Nacional, 195p. (Série Livros, 23).

Casatti, L. \& R. M. C. Castro. 2006. Testing the ecomorphological hypothesis in a headwater riffles fish assemblage of the rio São Francisco, southeastern Brazil. Neotropical Ichthyology, 4: 203-214.

Casatti, L., C. P. Ferreira \& F. R. Carvalho. 2009. Grass-dominated stream sites exhibit low fish species diversity and dominance by guppies: an assessment of two tropical pasture river basins. Hydrobiologia, 632: 273-283.

Dolédec, S., D. Chessel, C. J. F. Ter Braak \& S. Champley. 1996. Matching species traits to environmental variables: a new three-table ordination method. Environmental and Ecological Statistics, 3: 143-166.

Dray, S. \& A.-B. Dufour. 2007. The ade4 package: implementing the duality diagram for ecologists. Journal of Statistical Software, 22: 1-20.

Dray, S. \& P. Legendre. 2008. Testing the species traitsenvironment relationships: the fourth-corner problem revisited. Ecology, 89: 3400-3412.

Gatz, A. J., Jr. 1979. Ecological morphology of freshwater stream fishes. Tulane Studies in Zoology and Botany, 21: 91-124.

Goldstein, R. M. \& M. R. Meador. 2005. Multilevel assessment of fish species traits to evaluate habitat degradation in streams of the upper Midwest. North American Journal of Fisheries Management, 25: 180-194.

Hausner, V. H., N. G. Yoccoz \& R. A. Ims. 2003. Selecting indicator traits for monitoring land use impacts: birds in northern coastal birch forests. Ecological Applications, 13: 999-1012.

Hora, S. L. 1930. Ecology, bionomics and evolution of the torrential fauna, with special reference to the organs of attachment. Philosophical Transactions of the Royal Society of London, B: Biological Society, 218: 171-282 + appendix.

Instituto de Pesquisas Tecnológicas do Estado de São Paulo (IPT). 1999. Diagnóstico da situação atual dos recursos hídricos e estabelecimento de diretrizes técnicas para a elaboração do Plano da Bacia Hidrográfica do Turvo/Grande ( Relatório Técnico $\mathrm{n}^{\mathrm{o}}$ 40.515) - Relatório Final, Comitê da Bacia Hidrográfica do Turvo/Grande, Fundo Estadual de Recursos Hídricos. São Paulo, 1999, 3v.

Kamdem Toham, A. \& G. G. Teugels. 1999. First data on an Index of Biotic Integrity (IBI) based on fish assemblages for the assessment of the impact of deforestation in a tropical West African river system. Hydrobiologia, 397: 29-38.

Keck, B. P., Z. H. Marion, D. J. Martin, J. C. Kaufman, C. P. Harden, J. S. Schwartz \& R. J. Strange. 2014. Fish functional traits correlated with environmental variables in a temperate biodiversity hotspot. PLoS ONE, 9: e93237.

Kleyer, M., S. Dray, F. de Bello, J. Lepš, R. J. Pakeman, B. Strauss, W. Thuiller \& S. Lavorel. 2012. Assessing species and community functional responses to environmental gradients: which multivariate methods? Journal of Vegetation Science, 23: 805-821.

Lorion, C. M. \& B. P. Kennedy. 2009. Riparian forest buffers mitigate the effects of deforestation on fish assemblages in tropical headwater streams. Ecological Applications, 19: 468-479. 
Mahon, R. 1984. Divergent structure in fish taxocenes of north temperate streams. Canadian Journal of Fisheries and Aquatic Sciences, 41: 330-350.

McKinney, M. L. \& J. L. Lockwood. 1999. Biotic homogenization: a few winners replacing many losers in the next mass extinction. Trends in Ecology \& Evolution, 14: 450-453.

Melo, A. S. \& L. U. Hepp. 2008. Ferramentas estatísticas para análises de dados provenientes de biomonitoramento. Oecologia Brasiliensis, 12: 463-486.

Monbeig, P. 1998. Pioneiros e fazendeiros de São Paulo. 2. ed. São Paulo, Hucitec, 392p. (Geografia: teoria e realidade, v. 11).

Nalon, M. A., I. F. A. Mattos \& G. A. D. C. Franco. 2008. Meio físico e aspectos da fragmentação da vegetação. Pp. 15-21. In: Rodrigues, R. R., C. A. Joey, M. C. W. Brito, A. Paese, J. P. Metzger, L. Casatti, M. A. Nalon, N. Menezes, N. M. Ivanauskas, V. Bolzani \& V. L. R. Bononi. (Coords.). Diretrizes para a conservação e restauração da biodiversidade no estado de São Paulo. São Paulo, Secretaria do Meio Ambiente, Instituto de Botânica, Faspesp, Programa Biota/ Fapesp.

Oliveira, E. F., E. Goulart, L. Breda, C. V. Minte-Vera, L. R. S. Paiva \& M. R. Vismara. 2010. Ecomorphological patterns of the fish assemblage in a tropical floodplain: effects of trophic, spatial and phylogenetic structures. Neotropical Ichthyology, 8: 569-586.

Pease, A. A., A. A. González-Días, R. Rodiles-Hernández \& K. O. Winemiller. 2012. Functional diversity and trait-environment relationships of stream fish assemblages in a large tropical catchment. Freshwater Biology, 57: 1060-1075.

Petchey, O. L. \& K. J. Gaston. 2006. Functional diversity: back to basics and looking forward. Ecology Letters, 9: 741-758.

Pool, T. K., J. D. Olden, J. B. Whittier \& C. P. Paukert. 2010. Environmental drivers of fish functional diversity and composition in the Lower Colorado River Basin. Canadian Journal of Fisheries and Aquatic Sciences, 67: 1791-1807.

R Development Core Team. 2011. R: a Language and environment for statistical computing. Vienna, Austria, R Foundation for Statistical Computing. Available from: http://www.r-project. org/ (July 2012).

Ribera, I., S. Dolédec, I. S. Downie \& G. N. Foster. 2001. Effect of land disturbance and stress on species traits of ground beetle assemblages. Ecology, 82: 1112-1129.

Schleuter, D., M. Daufresne, J. Veslot, N. W. H. Mason, C. Lanoiselée, S. Brosse, O. Beauchard \& C. Argillier. 2012. Geographic isolation and climate govern the functional diversity of native fish communities in European drainage basins. Global Ecology and Biogeography, 21: 1083-1095.
Šidák, Z. 1967. Rectangular confidence regions for the means of multivariate normal distributions. Journal of the American Statistical Association, 62: 626-633.

Silva, A. M., M. A. Nalon, F. J. N. Kronka, C. A. Álvares, P. B. Camargo \& L. A. Martinelli. 2007. Historical land-cover/use in different slope and riparian buffer zones in watersheds of the State of São Paulo, Brazil. Scientia Agricola, 64: 325-335.

StatSoft Inc. 2004. STATISTICA (data analysis software system), version 7. Available from: htpp://www.statsoft.com (July 2012).

Strahler, A. N. 1957. Quantitative analysis of watershed geomorphology. Transactions, American Geophysical Union, 38: 913-920.

Teresa, F. B. \& L. Casatti. 2012. Influence of forest cover and mesohabitat types on functional and taxonomic diversity of fish communities in Neotropical lowland streams. Ecology of Freshwater Fish, 21: 433-442.

Teresa, F. B., L. Casatti \& M. V. Cianciaruso. 2015. Functional differentiation between fish assemblages from forested and deforested streams. Neotropical Ichthyology, 13: 361-370.

Townsend, C. R. \& A. G. Hildrew. 1994. Species traits in relation to a habitat templet for river systems. Freshwater Biology, 31: 265-275.

Vallet, J., H. Daniel, V. Beaujouan, F. Rozé \& S. Pavoine. 2010. Using biological traits to assess how urbanization filters plant species of small woodlands. Applied Vegetation Science, 13: 412-424.

Villéger, S., J. R. Miranda, D. F. Hernández \& D. Mouillot. 2010. Contrasting changes in taxonomic vs. functional diversity of tropical fish communities after habitat degradation. Ecological Applications, 20: 1512-1522.

Watson, D. J. \& E. K. Balon. 1984. Ecomorphological analysis of fish taxocenes in rainforest streams of northern Borneo. Journal of Fish Biology, 25: 371-384.

Winemiller, K. O. 1991. Ecomorphological diversification in lowland freshwater fish assemblages from five biotic regions. Ecological Monographs, 61: 343-365.

Winemiller, K. O., D. B. Fitzgerald, L. M. Bower \& E. R. Pianka. 2015. Functional traits, convergent evolution, and periodic tables of niches. Ecology Letters, 18: 737-751.

Submitted December 12, 2014 Accepted October 30, 2015 by William Crampton 